\title{
Sistem OLOC(One Like One Coment) Pada Media Sosial Ditinjau Dari Etika Pemasaran Islam
}

\author{
Dessy Asnita* dan Agustinar** \\ Institut Agama Islam Negeri Langsa \\ *dessyasnitadessy@gmail.com \\ **agustinar@iainlangsa.ac.id
}

\begin{abstract}
ABSTRAK
Penelitian ini bertujuan untuk mengetahui bagaimana sistem One like one comment (OLOC) media sosial ditinjau dari Etika Pemasaran Islam?Dalam penelitian ini penulis menggunakan Metode penelitian ORM (Online Research Method) dengan mengumpulkan berbagai data dari internet. Berdasarkan hasil penelitian, dapat disimpulkan bahwa Sistem One Like One Comment (OLOC) pada Media Sosial sangat berbeda dengan Etika pemasaran dalam Islam, banyak prosedur dan ketentuan yang tidak sesuai dengan Etika Pemasaran Islam dan melanggar prinsip-prinsip dari pemasaran Islam seperti Prinsip keadilan, kejujuran, transparansi dan profesionalitas. Dalam Etika pemasaran Islam seorang pebisnis baik itu pebisnis konvensional, tradisional maupun pebisnis onlineshop harus selalu mengedepankan dan menerapkan etika yang baik dalam memasarkan dan mempromosikan produknya, sedangkan sistem One like one comment (OLOC) ini tidak menerapkan prinsip Etika Pemasaran Islam bahkan terkenas menghalalkan segala cara dalam kegiatan promosi seperti merekayasa pasar, mengelabui serta mengada-ngada pada setiap komentar. Kegiatan seperti ini jelas dilarang dalam Islam karena dapat merugikan Costumers karena banyak komentar produknya tidak sesuai dengan yang realita yang ada.
\end{abstract}

\section{Kata Kunci: Sistem One Like One Comment (OLOC) dan Etika Pemasaran Islam}

\begin{abstract}
This study aims to find out how the One like one comment (OLOC) social media system is viewed from Islamic Marketing Ethics? In this study the author uses the ORM (Online Research Method) research method by collecting various data from the internet. Based on the results of the study, it can be concluded that the One Like One Comment System on Social Media is very different from marketing ethics in Islam, many procedures and provisions are not in accordance with Islamic Marketing Ethics and violate the principles of Islamic marketing such as the principles of justice, honesty, transparency and professionality. In Islamic marketing ethics, a businessman, be it a conventional, traditional or online shop businessman, must always prioritize and apply good ethics in marketing and promoting his products, while the One like one comment (OLOC) system does not apply the principles of Islamic Marketing Ethics and is even known to justify all means in promotional activities such as market engineering., trick and make up on every comment. Activities like this are clearly prohibited in Islam because they can harm customers because many comments on their products do not match the existing reality.
\end{abstract}

Keywords: One Like One Comment (OLOC) System, Islamic Marketing Ethics 


\section{PENDAHULUAN}

Para pengusaha sering sekali melakukan segala cara untuk mendapatkan keuntungan sepihak dalam memasarkan produk-produknya, tidak memikirkan aturan serta etika-etika yang seharusnya ditaati untuk memasarkan produk-produknya. Padahal Islam sudah menjelaskan secara panjang lebar mengenai risalah bisnis mengenai jual beli dalam Islam dalam Fiqh Muamalah. Sebagai pengusaha muslim harusnya kita dapat mematuhi rambu-rambu lalu lintas yang sudah diajarkan oleh agama Islam dalam segala sisi kehidupan terlebih lagi dalam hal bisnis karena terkait dengan mencari nafkah yang halal (DalamIslamcom, 2021).

Instagram merupakan salah satu media sosial yang sangat diminati oleh masyarakat. Oleh karenanya banyak para pembisnis online menggunakan instagram sebagai salah satu untuk mengembangkan bisnisnya. One like one comment (OLOC) merupakan salah satu cara yang digunakan para pembisnis online untuk meningkatkan penjualan di media sosial. One like one comment ini sering digunakan di instagram, namun tidak menutup kemungkinan digunakan untuk media sosial lainnya seperti Facebook dan line. Tujuan One like one comment (OLOC) diantaranya, untuk meningkatkan kepercayaan (trust) orang lain (calon customer), insight di setiap postingan dan meningkatkan kunjungan profil di akun instagram tersebut. Ini merupakan salah satu cara untuk menaikkan trafik penjualan agar postingan banyak dilihat oleh para pengguna media sosial. Para pembisnis online percaya bahwa semakin banyak yang menekan like dan semakin banyak yang comment pada postingan tersebut maka semakin besar pula ketertarikan costumer untuk membeli produknya. Artinya cara ini ingin menjadikan akun seorganik mungkin yaitu dengan meyakinkan orang-orang bahwa followersnya banyak, postingannya terlihat berkesan, dan ramai dikunjungi sehingga ini menjadi ketertarikan sendiri bagi pengguna media sosial untuk mengikuti dan melihat postingan dari pemilik akun.

One like one comment (OLOC) ini dilakukan dalam bentuk komunitas yaitu dengan memberikan likes dan comment pada postingan tertentu, dilakukan semanual mungkin agar tidak terkesan seperti buatan dan menghindari resiko akun akan dinonaktifkan (baned). Dan banyak juga yang membuat jasa One like one comment (OLOC) ini berbayar bahkan dengan menggunakan jasa boomlike. Penyebutan OLOC ini juga berbeda-beda tergantung yang membuatnya (Varamita, 2019). Penyebutannya juga 
berbeda-beda, Ada yang menyebutnya dengan jasa LFL yaitu like for like. Sebagaimana telah diketahui bahwa like mampu menaikkan jumlah insight dan menarik orang lain untuk mengunjungi profil pemilik akun. Dengan banyaknya like ini akan menaikkan postingannya masuk di pencarian teratas atau TOP pencarian agar akun berada dibagian teratas pada tagar yang digunakan, sehingga dengan menjadi popular tentu akan menambah kepercayaan (trust) calon costumer dikarenakan ramainya yang like dan comment di postingan instagram nya.

Jadi like dan commet ini sangat berpengaruh pada instagram. Sehingga para pedagang online banyak menggunakan jasa One like one comment (OLOC) ini pada akun istagram mereka agar online shop mereka banyak dikenal orang dan lebih dipercaya. Sehingga terkadang cara ini juga disalahgunakan untuk malakukan penipuan online, jumlah followers asli berbanding terbalik dengan pembeli. Faktanya algoritma pada instagram yang melihat postingan pada instagram kita hanyalah $10 \%$ dari jumlah follower yang akan melihat postingan kita. Sehingga karena inilah para pembisnis online di instagram banyak menggunakan jasa One like one comment (OLOC) untuk menambah like dan comment di akun bisnis instagramnya. Karena inilah penulis tertarik untuk meneliti bagaimana etika pemasaran dalam islam mengenai One like one comment (OLOC) ini.

Berdasarkan permasalahan di atas maka, maka rumusan masalah dalam penelitian ini adalah Bagaimanakah Sistem One like one comment (OLOC) Pada Media Sosial? Dan Bagaimanakah Sistem One like one comment (OLOC) Pada Media SosialDitinjau Dari Etika Pemasaran Islam?. Dalam tulisan ini penulis menggunakan Teori etika pemasaran dalam Islam dan sistem One like one comment (OLOC) pada Media Sosial.

\section{PEMBAHASAN}

\section{Teori Etika Pemasaran Dalam Islam}

Dalam Islam,Etika merupakan hasil atau buah dari keislaman, keimanan dan ketaqwaan yang berasal dari keyakinan terhadap keyakinan terhadap kebenaran Allah SWT. Islam sendiri merupakan sumber etika yang menyeluruh dalam segala lini kehidupan manusia, termasuk dalam bisnis. Sebuah Bisnis dalam Islam harus berdasarkan pada kepentingan untuk beribadah kepada Allah dengan niat karena mencari keridhaan dan mematuhi aturan Allah(Harahap, 2010). Bisnis Islam selalu memandang dua Area operasional, yaitu prinsip dasar bisnis yang telah ditetapkan dalam Alquran dan hadis yang 
tidak akan pernah berubah, dan kedua perkembangan terhadap ilmu pengetahuan(Shihab, 2011).

Secara bahasa kata Etika atau bahasa latinnya ethius berasal dari bahasa Yunani yaitu ethicos yang memiliki banyak arti yaitu akhlak, kebiasaan, watak, sikap, dan cara berfikir. Yang dimaksud dari kata ethos adalah kebiasaan baik atau kebiasaan buruk. Dalam pustaka umum, kata etika berarti sebagai ilmu. Sedangkan secara istilah etika adalah suatu pengetahuan yang membahas benar tidaknya atau baik-buruk tingkah laku dan tindakan manusia tentang kewajiban-kewajiban manusia(Haris, 2007). Etika juga merupakan sebuah ilmu yang berisi pedoman mengenai hal-hal yang benar atau salah, yang bermanfaat atau tidak bermanfaat dan yang baik atau buruk, juga merupakan bidang ilmu normatif yang berperan untuk menentukan sesuatu yang dilakukan oleh manusia secara individu(Muhammad, 2004).

Berdasarkan beberapa definisi diatas dapat penulis simpulkan bahwa Etika adalah sikap dan prilaku seseorang yang dapat menentukan baik buruknya dalam aktivitas seharihari.

Dalam Islam sudah ada ketentuan bahwa ketika menawarkan produk barang maupun jasa harus dilakukan dengan cara baik, sesuai dengan ketentuan Alqur'an dan Hadis. Barang atau jasa tersebut memang benar-benar dibutuhkan dan diinginkan oleh pembeli sendiri bukan karena desakan dari penjual. Transaksi yang terjadi harus atas suka sama suka, harmonis dan tidak ada paksaan ataupun tipuan dari pembeli.(Aziz, 2008)

Pemasaran merupakan suatu perencanaan atau eksekusi konsep dalam promosi, pengembangan, penempatan, distribusi ide, dan penentuan harga barang/jasa untuk menciptakan adanya pertukaran untuk memenuhi tujuan organisasi dan individu (A. Krasovec, 2007). Adapun tujuan dari pemasaran Tujuan untuk menarik lebih banyak konsumen/pembeli terhadap produk yang dipasarkan supaya lebih banyak mendapatkan keuntungan (Zyman, 2000).

Menurut Kertajaya dan Syakir Sula (Kertajaya Hermansyah dan Muhammad Syakir, 2006) Pemasaran Syariah adalah Sebuah strategi bisnis yang mengarahkan proses promosi, penawaran, penciptaan, dan perubahan nilai value dari marketer kepada stakeholdersnya, yang keseluruhan prosesnya sesuai prinsip-prinsip dan akad-akad dalam muamalah (business) Islam. Jadi, pemasaran Islam merupakan seluruh proses penciptaan, perubahan nilai (value), maupun penawaran tidak boleh bertentangan dengan prinsip muamalah dan Ekonomi Islam. 
Etika pemasaran dalm Islam adalah etika berdasarkan prinsip-prinsip Islam dimana marketer dalam menjalankan fungsi-fungsi pemasaran secara Islami, seperti jujur (transparan), bertakwa kepada Allah (kepribadian spiritual), berlaku adildalam bisnis (AlAdl), menepati janji dan bersikap melayani(Kertajaya Hermansyah dan Muhammad Syakir, 2006).

Adapun prinsip etika pemasaran Islami, antara lain: a. Memiliki Kepribadian Spiritual (Takwa); b. Berlaku Adil dalam Bisnis (Al-Adl); c. Berlaku baik dan simpatik (Shidiq); d. Bersikap Melayani dan Rendah hati (Khidmah); e. Menepati janji dan Tidak Curang; f. Jujur dan Terpercaya (Al-Amanah); g. Tidak berburuk sangka (Su'udz zhan); h. Tidak suka menjelek-jelekkan (Ghibah); i. Tidak melakukan suap/sogok(riswah) (Kertajaya Hermansyah dan Muhammad Syakir, 2006).

Proses pemasaran adalah bagian penting promosi yang berupaya menawarkan dan mempromosikan barang dan jasa kepada konsumen (calon pembeli). Rasululah Saw memberikancontoh dan petunjuk mengenai etika pemasaran, di antaranya adalah:

1. Prinsip utama dan paling penting dalam bisnis adalah prinsip kejujuran. Dalam pembahasan ini, beliau bersabda: "Tidak dibenarkan seorang muslim menjual satu jualan yang mempunyai aib, kecuali ia menjelaskan aibnya” (H.R. Al-Quzwani).

"Siapa yang menipu kami, maka dia bukan kelompok kami” (H.R. Muslim). Nabi Muhammad SAW selalu bersikap jujur dalam berdagang (berbisnis). Nabi melarang para pedagang memasarkan dan meletakkan barang busuk di antara barang bagus.

2. Adanya kesadaran terhadap kegiatan Sosial dalam berbisnis. Pelaku bisnis tidak hanya mengejar keuntungan saja tetapi juga berorientasi dengan sikap ta'awun (saling tolong menolong) sebagai bentuk implikasi sosial dalam kegiatan bisnis. Tegasnya adalah dalam berbisnis, tidak hanya mencari keuntungan materi semata, tetapi juga adanya kesadaran untuk memberi kemudahan kepada orang lain dalam menjual barang.

3. Tidak melakukan sumpah palsu. Rasulullah saw, sangat intens dalam melarang pelaku bisnis melakukan sumpah palsu ketika berbisnis atau bertransaksi dalam memasarkan produknya. Sebagaimana dalam sebuah Hadis Rasulullah bersabda, "Dengan melakukan sumpah palsu, barang-barang memang terjual, tetapi hasilnya tidak berkah" (HR Bukhari). Dalam HR. Abu Dzar, Rasulullah saw mengancam dengan azab yang pedih bagi orang yang bersumpah palsu dalam bisnis, dan Allah tidak akan memperdulikannya nanti di hari kiamat (H.R. Muslim). Nabi Muhammad saw mengatakan, "Allah merahmati seseorang yang ramah dan toleran dalam berbisnis." (HR. Bukhari dan Tarmizi). 
4. Melarang berpura-pura menawar harga tinggi, supaya orang lain tertarik untuk membeli dengan harga tersebut. Sabda Nabi Muhammad, "Janganlah kalian melakukan bisnis najas (seorang pembeli tertentu, berkolusi dengan penjual untuk menaikkan harga, bukan dengan niat untuk membeli, tetapi agar menarik orang lain untuk membeli)". Muhammad Saw bersabda, Janganlah seseorang di antara kalian menjual dengan maksud untuk menjelekkan apa yang dijual oleh orang lain. (H.R. Muttafaq 'alaih).

\section{Teori One like one comment (OLOC)}

OLOC atau yang sering disebut One Like One Coment suatu kegiatan yang dilakukan bersama-sama atau berkelompok untuk merekayasa penjualan seakan-akan kegiatan ini real dilakukan dari pembeli/costumer (calon pembeli) yang bertujuan untuk menaikkan rating penejualan pada media sosial. kegiatan ini dilakukan secara bersamasama dalam 1 kelompok (1 group) dengan beberapa anggota owner/admin onlineshop, dilakukan pada jadwal yang sudah disepakati bersama(AlCreative, 2019).

Keuntungan dari One like one comment (OLOC) ini yaitu untuk membuat foto yang diposting oleh owner onlineshop terlihat banyak yang like dan coment sehingga kemungkinan besar postingan tersebut otomatis akan keluar pada pencarian teratas pada menu eksplores ini juga termasuk promosi terselubung, namun dibuat seorganik mungkin untuk meningkatkan jumlah followers, konversi penjualan tinggi dan engagementnya juga tinggi.

Hal ini dilakukan melihat pada kenyataan yang sering terjadi dilapangan adalah biasanya calon costumer ketika melihat onlineshop yang amanah/terpercaya, mereka akan melihat dari jumlah komentar dan juga jumlah like yang ada. Jadi ini sangat mempengaruhi dari segi kredibilitas akun onlineshop yang dimiliki oleh seseorang dan juga berpengaruh pada penjualannya.

Ada beberapa trik yang diyakini oleh para owner olshop untuk meningkatkan penjualan Salah satunya yang sedang populer yaitu dengan meningkatkan likes dan comment pada postingan per foto. Para owner olshop media sosial percaya bahwa dengan semakin banyak likes dan comment, maka semakin besar ketertarikan dan raya percaya orang untuk membeli produt tersebut (Evalotta, 2019).

Berdasarkan uraian diatas dapat disimpulkan bahwa, One like one comment (OLOC) merupakan sebuah tindakan yang sengaja dibuat untuk merekayasa penjualan 
sehingga calon customer akan semakin percaya kepada olshop tertentu karena melihat banyaknya interaksi seperti jumlah like yang banyak, pertanyaan banyak dan fast respon pada kolom komentarnya.

\section{METODOLOGI}

Dalam artikel ini penulis menggunakan metode penelitian ORM (Online Research Method), yakni peneliti mengumpulkan data melalui internet dan metode berbasis web. Adapun Data primer dalam artikel ini yaitu data yang diperoleh dari Media Sosial tentang One like one comment (OLOC) dan juga berasal dari beberapa literatur lainnya tentang etika pemasaran dalam Islam. Sedangkan data sekunder dalam artikel ini yaitu data yang penulis peroleh secara tidak langsung dari subjek penelitinya dan dari referensi lainnya yang bisa dijadikan rujukan tambahan untuk penelitian ini (Fathoni, 2011).

\section{HASIL DAN PEMBAHASAN}

\section{Sistem One Like One Comment (OLOC) Media Sosial}

Branding sangat berpengaruh dalam meningkatkan penjualan baik penjualan melalui offline maupun online. Dalam penjualan online, branding juga tidak kalah pentingnya terutama di media sosial khususnya instagram. One like one comment (OLOC) adalah salah satu optimasi IG yang bertujuan untuk mempertinggi insight di instagram. Pembisnis online memposting barangnya di Media sosial tentu tujuannya untuk dilihat banyak orang serta membuat orang untuk tertarik membelinya. Karena orang tidak akan percaya terhadap toko toko online yang masih sepi pengunjungnya. Oleh karena itulah banyak toko-toko online membuat fasilitas berupa One like one comment (OLOC) ini. Fasilitas ini khusus untuk reseller dan mitranya saja tetapi dengan syarat misalnya order 12 pcs atau 1 seribarang ready stok atau ikut pre order(PO) barang yang belum ready, kemudian setelah memenuhi syarat barulah digabungkan ke dalam grup yang anggotanya semuanya akan mengikutione like one koment (OLOC) (Fitri Fairez Shop, 2021).

Fasilitas OLOC, TLOC, dan 2LC bisa dipakai di media sosial apapun tergantung kesepakatan dari admin dan para anggota grup dan nanti dibuat jadwal sesuai event yang disepakati.Namun yang sering dipakai adalah pada akun FB maupun instagram karena dua media sosial inilah yang paling banyak digunakan oleh pembisnis online.

Menurut admin One like one comment (OLOC) serta para anggota yang ikut serta di dalamnya menyatakan bahwa tujuan paling penting dari melakukan event komentpada medsos bukanlah untuk membohongi calon pembeli. Namun Ingin membantu serta 
memudahkan customer dengan pertanyaan pertanyaan atau pujian yang disesuaikan dengan picture dan captionnya.Sehingga calon pembeli tidak perlu bertanya-tanya lagi untuk pertanyaan yang sama juga intinya untuk membantu menaikkan rating produk si penjual online agar statusnya naik ke atas sehingga terlihat terus di beranda followers.Dalam hal ini mereka juga memberikan batasan pada Comment-Comment yang akan diberikan nantinya (wawancara Admin Fairez, 2021). Serta beberapa contoh Comment Positif yang disarankan untuk digunakan. Comment bisa berupa pertanyaan pertanyaan terhadapproduk yang diposting. Juga diperbolehkan untuk memberikan Coment berupa pujian terhadap produk tersebut. Menurut komunitas ini Coment berupa pujian terhadap produk tersebut, sangat diperbolehkan apabila dalam foto tersebut memang cantik dan bagus serta benar benar disukai. Tetapi jika tidak sesuai atau tidak bagus atau tidak suka maka sangat tidak diperbolehkan coment pujian. Jadi walaupun fasilitas ini seolah mengada-ngada namun tidak melakukan kebohongan. Jadi dalam komunitas ini ada beberapa ketentuan diantaranya; 1) Diperbolehkan memberikan pujian terhadap suatu postingan, 2) Dilarang pelit comment misalnya hanya coment 1 atau 2 kata, 3) Dilarang comment yang berisi kebohongan. Yang membuat sedikit membingungkan dalam syarat ini adalah bagaimana bisa seseorang memberikan komentar yang jujur tanpa kebohongan sedangkan tidak pernah membeli atau melihat langsung barang tersebut.

Kemudian syarat selanjutnya adalah Memiliki dua (2) akun yang berbeda. Satunya akun bisnis dan satunya akun pribadi. Nantinya onlineshop akan memposting barangnya di akun jualan kemudian akan bekerja menggunakan One like one comment (OLOC) memakai akun pribadi dengan tujuan akan lebih terlihat Natural. Event comment ini adalah para online shop saling membantu dan bekerjasama dengan baik. Diharapkan Comment yang di dapat akan membuat para calon pembeli percaya dan tertarik untuk belanja di online shop dan Membantu Menaikkan Rating Produk online shopsehingga bisa masuk di Top Hastag(pictureterpopuler berdasarkan Hastag) tentunya juga disertai dengan Event Like For Like (LFL) juga membantu postingan kita tetap muncul di beranda followers.

\section{Etika Pemasaran Terhadap Sistem One Like One Comment (OLOC) Media Sosial}

Dalam Islam sistem pemasaran selalu mengajarkan produsen dan distributor untuk jujur dan amanah pada costumer dan juga semua orang. Pemasaran Islam bukan hanya sebuah sistem pemasaran yang hanya ada penambahan kata syariahpada Pemasaran Syariah saja, akan tetapi lebih pemasaran berperan dalam nilai-nilai syariah, dan nilai 
syariah itu berperan dalam pemasaran yang dilakukan oleh para pemasar baik itu produsen, distributor, maupun penjual.

Pengharapan yang sangat besar bahwa dalam pemasaran perusahaan berbasis syariahdapat bersikap profesional ketika berbisnis, sebab dengan sikap profesionalitas dapat menghadirkan kepercayaan konsumen. Pemasaran Islami berperan untuk menumbuhkan pemahaman akan pentingnya moralitas dan nilai-nilai etika Islam, sehingga perusahaan diharapkan tidak akan menjalankan bisnisnya hanya demi keuntungan individu/pribadi saja melainkan juga harus berusaha untuk menawarkan, menciptakan dan merubah suatu nilai guna kepada para penggunanya (stakeholders)yang pada akhirnya perusahaan itu dapat menjagaequilibrium(keseimbangan)siklus dari bisnisnya.

Menurut (Malahayatie, 2019), Suatu bisnis bisa dikatakan sustainable apabila dapat mewujudkan tujuan dari sistem pemasaran etika bisnis islam, seperti: a. Syariah Marketing Strategy; b. Syariah Marketing Tactic; c. Syariah Marketing Value; d. Syariah Marketing Scorecard; dan e. Syariah Marketing Enterprise. Kelima sistem marketing ini bertujuan untuk memenangkan mind-shareyang dilakukan dengan pemetaan pasar, untuk menghasilkan keuntungan financial dengan melakukan penerapan diferensiasi yang kreatif dan inovatif menggunakan pemasaran campuran/marketing mix (product, price, place and promotion), untuk heart-share (kecintaan pelanggan terhadap produk). Semua strategi ini dilakukan untuk mengoptimalkan value dari produk/barang dan jasa yang dijual. Peningkatan value merupakan sebuah upaya untuk membangun brand yang kuat, memberikan servis sesuai dengan keinginan pelanggan sehingga pelanggan (costumer) loyal.

Dalam pemasaran Islam, brand merupakan sebuah identitas perusahaan atau seseorang yang harus dijaga. Contohnya seperti Rasulullah SAW yang sudah terkenal sebagai seorang Al-Amin, jadi ketika beliau memasarkan produknya lebih mudah dalam mengkomunikasikannya karena semua orang sudah percaya. Dalam menciptakan keseimbangan nilai guna (value), ada tiga stakeholdersutama dari suatu perusahaan untuk menjalankan sebuah perusahaan, yaitu customers, people, dan shareholders. Dan tujuan yang terakhir yaituuntuk menciptakan inspirasi (inspiration)yang akan membimbing manusia, dan juga perusahaan.

Menurut (Toriquddin, 2010), ada 3 Etika pemasaran dalam Perspektif Al qur'an, antara lain:

1. Bersikap sopan santun dan lemah lembut 
Dalam melakukan promosi seorang pelaku bisnis harus sopan santun dan ramah dengan menggunakan kata-kata yang lembut dalam promosi. Sebagaimana firman Allah dalam Alquran Surah an-Nahl ayat 25, yang berbunyi:

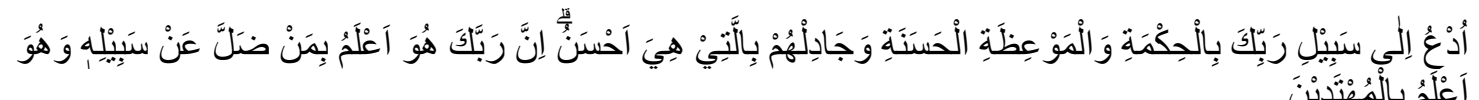

Artinya: Serulah (manusia) kepada jalan Tuhanmu dengan hikmah dan pengajaran yang baik, dan berdebatlah dengan mereka dengan cara yang baik. Sesungguhnya Tuhanmu, Dialah yang lebih mengetahui siapa yang sesat dari jalan-Nya dan Dialah yang lebih mengetahui siapa yang mendapat petunjuk.(QS. An-Nahl: 125).(Departemen Agama, 2006)

Rasulullah SAW pernah menegaskan bahwa Allah selalu memberikan rahmat kepada orang-orang yang ramah dan bersikap toleran dalam bisnis.Seorangpenjual yangbaik mempunyai kemampuan dalam bertutur sapa dan lemah lembut dalam bersikap seperti yang dicontohkan oleh Rasulullah SAW ketika berbisnis. Sopan santun dan lemah lembuh juga dapat menghadirkan rasa simpati, kepercayaan, muncul kepuasan bagi konsumen karena merasa nyaman dalam bertransaksi dengan penjual/marketer.

Sistem One like one comment (OLOC) ini sudah memenuhi kriteria sikap sopan dan lemah lembuh santun dan lemah lembut karena semua bahasa komentar yang digunakan oleh peserta One like one comment (OLOC) benar-benar disaring dengan kalimat yang sesuai dengan standar yang telah ditetapkan oleh admin group, jadi semua bahasa komentar harus sesuai aturan yang telah disepakati. Berdasarkan hal ini dapat disimpulkan bahwa, untuk teori etika pemasaran dari segi lemah lembut dan sopan santun sistem One like one comment (OLOC) memenuhi syarat.

\section{Profesional dalam Promosi}

Profesionalitas dalam pemesaran harus bersikap adil dalam promosi. Dalam berbisnis Allah sangatlah melarang seseorang beperilaku curang, melakukan sesuatu yang mengandung unsur kebohongan atau gharar, menggabungkan antara kebenaran dan kebathilan, dan manipulasi,baik dalam menjelaskan kualitas produk, harga atau banyaknya jumlah pemesanan. Etika pemasaran Islam selalu mengutamakan kejujuran. Nabi Muhammad SAW telah memberikan pedoman bahwa seorang pedagang yang jujur, ikhlas, tulus dan dapat dipercaya adalah golongan yang masuk syurga bersama Rasul. Sikap adil 152 
inilah menjadi pedoman dalam berbisnis. Dalam AlQuran (QS Al Isra: 35), Allah berfirman:

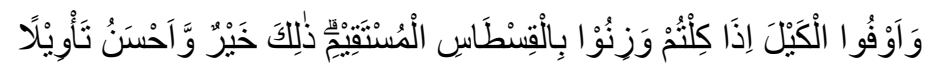

Artinya: Dan sempurnakanlah takaran apabila kamu menakar, dan timbanglah dengan timbangan yang benar. Itulah yang lebih utama (bagimu) dan lebih baik akibatnya. (QS. Al Isra: 35). (Departemen Agama, 2006)

Dari ayat tersebut Allah memerintahkan, dalam berbisnis haruslah bersikap adil, tidak berat sebelah, tidak bengkok dan terhindar dari unsur penipuan. Bersikap adil yang dimaksud disini bukan hanya terhadap orang muslim saja, melainkan juga terhadap konsumen-konsumen non muslim, sehingga konsep pemasaran Islam terimplementasikan bagi seluruh orang yang bertransaksi dengannya. Keadilan diwujudkan dari berbagai aspek kehidupan, seperti masalah sosial, ekonomi, keluarga, politik dan lingkungan.

Teori pemasaran Islam menegaskan bahwa bersikap adillah kepada semua klien tanpa membedakan suku, agama, bangsa dan tanpa memandang status sosial. Hal ini juga Allah tegaskan dalam QS. Al-mumtahanah ayat 8:

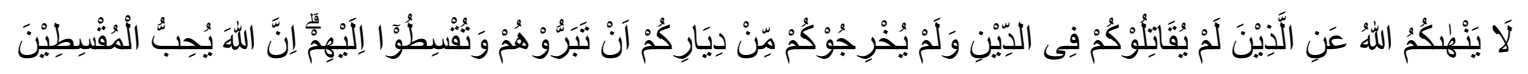

Artinya: Allah tidak melarang kamu berbuat baik dan berlaku adil terhadap orang-orang yang tidak memerangimu dalam urusan agama dan tidak mengusir kamu dari kampung halamanmu. Sesungguhnya Allah mencintai orang-orang yang berlaku adil. (QS. Al Mumtahanag: 8)(Departemen Agama, 2006)

Dalam ayat ini Allah membolehkan berinteraksi secara baik dengan non muslim dan melarang berkasih sayang dengan kaum musyrik yang memusuhimu. Begitu juga dalam hal bisnis, berlaku adil juga berlaku untuk orang-orang non muslim.

Seorang marketer dalam harus bersikap profesional dalam mempromosi produk yang menjadi sebuah landasan agar tetap berjalan pada koridor kejujuran atau selalu bersikap amanah, mengedepankan keadilan, teguh pada kebenaran, dan keberkahan dengan mencari keridhoan Allah SWT. Landasan atau aturan-aturan inilah yang menjadi landasan hukum dalam berbisnis secara Islami (Islamic business). Berdasarkan teori di atas sistem One like one comment (OLOC) sangat jauh dari etika promosi yang 
digambarkan dalam Islam, tidak professional dalam promosi, tidak mempedulikan keadilan, tidak jujur, menghalalkan segala cara untuk mendapatkan keuntungan. Jelas hal itu sangatlah bertentangan dengan etika pemasaran Islam dan dilarang dalam Islam yang selalu mengedepan kan konsep keadilan kejujuran dalam berbisnis.

Ada tiga rukun dan syarat jual beli yang harus dipenuhi dalam Fiqh Muamalah diantara, yaitu a. Ijab kabul (aqad), b. orang-orang yang berakad, penjual dan pembeli, adapun syarat penjual dan pembeli sama-sama harus jujur, bertanggung jawab dan profesional); dan c. objek akad (ma'qud alaih) (Yunus et al., 2018). Adanya unsur profesionalitas, transparansi, akad dan keberadaan suaru barang (objek) yang diperjualbelikan juga menjadi rukun dan syarat yang menjadi objek penting dalam suatu bisnis maupun jual beli dalam Islam (Agustinar, 2021) Jika ditinjau dari Fiqh Muamalah event One like one comment (OLOC) ini melanggar rukun dan syarat yang telah ditetapkan oleh Islam yaitu tidak jujur dan transaparansi dalam melakukan jual beli. dalam rukun jual beli salah satu ojeknya adalah penjual dimana syarat penjual haruslah transparansi dan Jujur. dengan begitu maka event One like one comment (OLOC) ini tidak mengandung transparansi antara penjual dan pembeli dalam hal mengelabui calon pembeli dengan komentar komentar palsu dan ini tidak diperbolehkan dalam Islam.

3. Trasparan Dalam Pemasaran

Suatu bisnis dikatakan mengandung unsur transparansi dalam pemasaran Islami jika realistis, bertanggung jawab dan tidak menggunakan cara yang bathil.

a. Dalam Syariat Islam suatu bisnis dilarang merampas hak kekayaan orang lain dan mengadung unsur tidak halal. Adanya ketidakadilan karena disebabkan oleh semua prilaku bisnis dan tindakan yang tidak dikehendaki. Maka ajaran Islam sangat menjaga solidaritas sosial, menjaga hak-hak individual, dan mengenalkan nilai moralitas untuk mengimplementasikan aturan hukum Allah dalam bisnis(Ahmad, 2001).

Dalam Al quran Surah An-Nisa ayat 29, Allah menegaskan Larangan cara yang Bathil, yaitu:

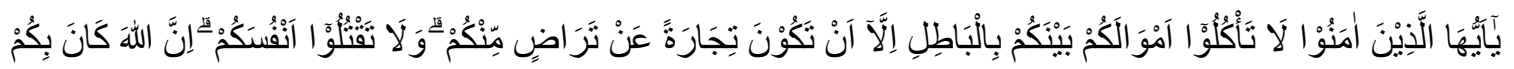

Artinya: Wahai orang-orang yang beriman! Janganlah kamu saling memakan harta sesamamu dengan jalan yang batil (tidak benar), kecuali dalam perdagangan yang berlaku atas dasar suka sama suka di antara kamu. Dan janganlah kamu 
membunuh dirimu. Sungguh, Allah Maha Penyayang kepadamu (QS. An Nisa: 29). (Departemen Agama, 2006)

Ayat tersebut menjelaskan bahwa tidak boleh memakan harta sesama dengan cara bathil kecuali melalui jalan perniagaan. Para pelaku bisnis sangat ditekankan untuk mengindahkan ketentuan-ketentuan yang sudah ditetapkan dalam Al Quran atau menjalankan persyaratan yang telah disepakati bersama sejauh tidak menghalalkan semua hal.

b. Realistis adalah salah satu etika pemasaran yang terdapat dalam Etika Bisnis Islam. Pemasaran Islam bersifat fleksibel, tidak bersifat fanatis, eklusif, kaku dan anti modernitas. Para marketer dalam Islam selalu berpenampilan rapi, bersih, dan bersahaja. Bekerja dengan mengedepankan nilai religiusitas, bermoral, keshalehan, dan mengedepankan prinsip kejujuran dalam berbagai aspek pemasaran (Kertajaya dan Syakir, 2006).

c. Dalam melakukan aktifitas pemasaran seorang marketer harus bertanggung jawab, karena jenis pemasaran apapun yang dilakukan akan diminta pertanggungjawabannya di dunia dan akhirat. Contohnya: tidak melakukan penipuan, memalsukan produk atau marketingnya sebab hal itu dapat menyebabkan kezaliman, kerugian sehingga akan menghadirkan perecokan dan permusuhan. Zaman sekarang telah banyak kita saksikan adanya praktik-praktik bisnis yang tidak terpuji yang dilakukan oleh para pebisnis dalam memasarkan produknya, tentunya yang dilarang dalam Islam, seperti:

1) Pengakuan testimoni fiktif dalam penawaran, contohnya seorang artis memberikan testimoni keunggulan suatu produk padahal dia sendiripun tidak menggunakannya;

2) Iklan yang tidak sesuai dengan realita, contoh: banyak iklan yang muncul dimedia masa televisi, media sosial, media cetak atau radio yang memberikan keterangan palsu;

3) Eksploitasi Wanita, contoh: pemasaran produk kosmetik yang sering menjadikan tubuh wanita sebagai bentuk dari komodifikasi agar iklan lebih menarik atau dalam pertunjukan-pertunjukan yang mempertontonkan wanita berpakain minim dan merayu pembeli untuk memberi produk yang mereka tawarkan.

Hal ini tentunya sangat bertentangan dengan Alqur'an yang memerintahkan untuk melakukan pemasaran secara bertanggung jawab, sebagaimana firman Allah pada ayat beriku ini:

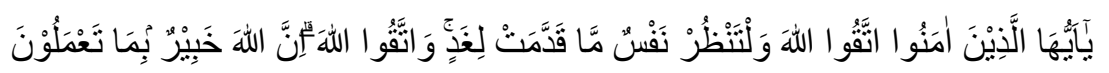


Artinya: Wahai orang-orang yang beriman! Bertakwalah kepada Allah dan hendaklah setiap orang memperhatikan apa yang telah diperbuatnya untuk hari esok (akhirat), dan bertakwalah kepada Allah. Sungguh, Allah Mahateliti terhadap apa yang kamu kerjakan. (QS. Al Hasyr: 18)(Departemen Agama, 2006).

Selain hal itudalam Bisnis, seorang penjual harus menjelaskan secara transparan tentang produknya kepada pembeli. Tidak saling kecoh mengecohkan dalam transaksi atau segala sesuatu yang mengandung gharar(penipuan). Dalam Hadis NabiS.A.W bersabda:

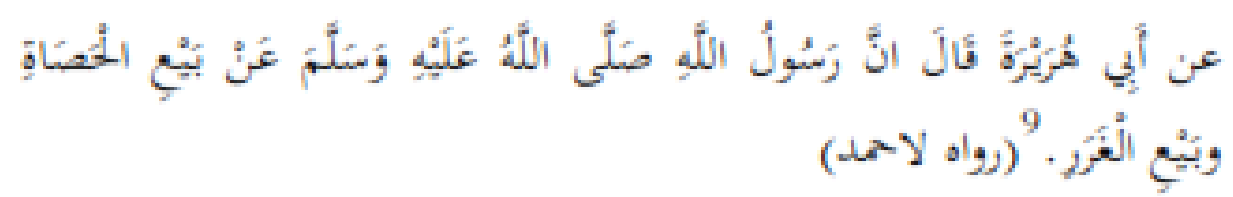

Artinya: Dari Abu Hurairah, Sesungguhnya Rasulullah SAW Bersabda, Rasul melarang jual beli dengan lemparan dan yang mengandung Gharar (Penipuan) (HR. Ahmad).

Menurut hadist di atas transaksi bisnis/jual beli tidak boleh mengandung penipuan (gharar)seperti jual kucing dalam karung tidak diketahui jenis dari kucing tersebut dan apakah itu benaran kucing atau tidak. Begitu juga Sistem One like one comment (OLOC) tidak diketahui hal yang sebenarnya dari produk yang dipasarkan karena sesmua mengandung rekayasa.

Jelas sekali bahwa event One like one comment (OLOC) ini bertentangan dengan dengan syariat islam apalagi dalam hal transparansi dalam pemasaran, komentar-komentar palsu yang dilakukan oleh pesesrta One like one comment (OLOC) jelas sekali akan mengelabui para calon konsumen, karena konsumen akan mengira bahwa komentarkomentar yang diberikan adalah calon pembeli real sehingga secara tidak langsung orangorang yang melihat postingan tersebut akan terpengarh untuk membeli produk tersebut. Seandainya barang yang dibeli tidak sesuai seperti yang ada di komentar ini akan menyebabkan kerugian serta ketidakrelaan bagi si pembeli. Event One like one comment (OLOC) ini bersifat gharar, sebagaimana hadis rasullullah bahwa jual beli yang mengandung unsur gharar itu tidak diperbolehkan. 
Para pengusaha sering sekali melakukan segala cara untuk mendapatkan keuntungan sepihak dalam memasarkan produk-produknya, mereka tidak memikirkan aturan serta etika-etika yang seharusnya ditaati untuk memasarkan produk-produknya. Padahal Islam sudah menjelaskan secara panjang lebar mengenai risalah bisnis menenai jual beli dalam Islam dalam fiqh muamalah. Sebagaipengusaha muslim harusnya kita dapat mematuhi rambu-rambu lalu lintas yang sudah diajarkan oleh agama islam dalam segala sisi kehidupan terlebih lagi dalam hal bisnis karena terkait dengan mencari nafkah yang halal.

Bagi Seorang dalam bermuamalah sangat diutamakan kejujuran. seorang pebisnis online harus memiliki sifat jujur, sehingga dalam proses jual beli tidak ada unsur penipuan atau seolah olah mengelabui custumer sehingga jual beli yang dihasilkan mendapatkan keberkahan. Menurut penulis faslitas atau event One like one comment (OLOC) ini bertentangan dengan prinsip berbinis karena sebagaimana kita ketahui bahwa kegiata OLOC ini terkesan membohongi calon customer.

Sebagaimana yang telah dipaparkan diatas bahwa One like one comment (OLOC) ini bertujuan untuk menaikkan rating pebisnis online agar postingannya terlihat paling atas saat dilakukan pencarian dan ini meruvakan salah satu strategi dalam berbisnis online. namun yang perlu kita garis bawahi adalah bahwa dalam melakukan strategi apapun harus berdasarkan prinsip-prinsip yang telah diperintahkan oleh agama islam. Sebagaimana kaidah fiqh ekonomi bahwa hukum asal muamalah boleh kecuali jika ada dalil yang mengharamkannya. dan sangat jelas sekali bahwa event One like one comment (OLOC) ini bertentangan dengan prinsip islam dari segi apapun, sehingga sebaiknya para pebisnis online mencari cara yang lebih baik lagi agar mendapat keberkahan dalam bermuamalah.

\section{KESIMPULAN}

Berdasarkan analisis penulis di atas, maka dapat disimpulkan bahwa:

1. One Like One Comment (OLOC) adalah salah satu cara yang digunakan para pembisnis online untuk meningkatkan penjualan di media sosial dan juga merupakan suatu kegiatan yang dilakukan bersama-sama atau berkelompok untuk merekayasa penjualan seakan-akan kegiatan ini real dilakukan dari pembeli/costumer (calon pembeli) yang bertujuan untuk menaikkan rating penejualan pada media sosial. Tujuan One like one comment (OLOC) diantaranya, untuk meningkatkan kepercayaan (trust) orang lain (calon customer), insight disetiap postingan dan meningkatkan kunjungan profil di akun instagram tersebut. 
Ini merupakan salah satu cara untuk menaikkan trafik penjualan agar postingan kita banyak dilihat oleh para pengguna media sosial. One like one comment (OLOC) dilakukan secara bersama-sama dalam 1 kelompok (1 group) dengan beberapa anggota owner/admin onlineshop, dilakukan pada jadwal yang sudah disepakati bersama.

2. Sistem One like one comment (OLOC) pada Media Sosial tidak sesuai dengan Etika Pemasaran Islam karena melanggar prinsip-prinsip dari etika pemasaran Islam seperti Prinsip kejujuran, keadilan, transparansi dan profesionalitas. Dalam pemasaran Islam seorang pebisnis online harus selalu menerapkan etika yang baik dalam mempromosikan produknya, sedangkan sistem One like one comment (OLOC) ini menghalalkan segala cara dalam pemasaran seperti merekaya pasar, mengelabui serta mengada-ngada pada setiap komentar. Hal ini jelas sangat dilarang dalam Islam karena dapat merugikan konsumen jika produknya tidak sesuai dengan yang ada pada komentar-komentar.

\section{PUSTAKA ACUAN}

Ahmad, M. (2001). Etika Bisnis Dalam Islam,Jakarta: Pustaka Al-Kautsar.

Agustinar, A. (2021). PERLAKUAN AKUNTANSI TERHADAP PEMBIAYAAN MURABAHAH. Al Mashaadir: Jurnal Ilmu Syariah, 2(1), 27-48. https://doi.org/10.52029/JIS.V2I1.38

AlCreative. (2019). Melayani Kebutuhan Bisnis Media Sosial. https://alcreativeindonesia.blogspot.com/2019/09/apasih-sfs-lfl-oloc-itu.html.

Aziz, A. (2008). Ekonomi Islam: Analisis Mikro dan Makro. Yogyakarta: Graha Ilmu.

DalamIslamcom. (2021). Etika Pemasaran Dalam Islam dan Prinsipnya. https://dalamislam.com/hukum-islam/ekonomi/etika-pemasaran-dalam-islam.

Departemen Agama. (2006). Departemen Agama (Depag) Republik Indonesia, "AlQur'an dan Terjemahannya", Jakarta: Cahaya Al-Qur,an.

Evalotta. (2019). Meningkatkan Penjualan IG dengan One Like One Comment (OLOC). http://tipsjualaninstagram.blogspot.com/2016/03/meningkatkan-penjualan-ig-denganone.html.

Fathoni, A. (2011). Metodologi Penelitian \& Teknik Penyusunan Skripsi. Jakarta:Rineka Cipta.

Fitri Fairez Shop. (2021). WAgroup PRA AGEN FAIREZ SHOP. https://web.whatsapp.com/wagrouppraagenfairezshop.

Harahap, S. S. (2010). Etika Bisnis dalam Perpektif Islam. Jakarta: Salemba Empat.

Haris, A. (2007). Pengantar Etika Islam. Sidoarjo: Al-Afkar. 
Kertajaya Hermansyah dan Muhammad Syakir. (2006). Syari'ah Marketing. Jakarta: Mizan.

Malahayatie. (2019). Etika Marketing dalam Perspektif Islam. Jurnal JESKape, Vol.2 No., 75-93.

Marianne Rosner Limchuk \& Sandra A. Krasovec. (2007). Desain Kemasan. Jakarta: Erlangga.

Muhammad. (2004). Etika Bisnis Islam. Yogyakarta: UPP-AMP YKPN.

Shihab, M. Q. (2011). Bisnis Sukses Dunia Akhirat. Ciputat: Lentera Hati.

Toriquddin, M. (2010). ETIKA PEMASARAN PERSPEKTIFAL-QUR ' AN DAN RELEVANSINYA DALAM PERBANKAN SYARI'AH. 116-125.

Varamita, C. U. A. (2019). SEKILAS TENTANG OLOC/ TLOC/ 2LC. https://web.facebook.com/groups/419232348940035/posts/419431788920091/?_rdc= $1 \& \_$rdr.

Yunus, M., Hamdani, F. F. R. S., \& Shofia, G. K. (2018). Tinjauan Fikih Muamalah Terhadap Akad Jual Beli Dalam Transaksi Online Pada Aplikasi Go-Food. Amwaluna: Jurnal Ekonomi Dan Keuangan Syariah, 2(1), 135-146. https://doi.org/10.29313/amwaluna.v2i1.3363

Zyman, S. (2000). The end of Marketing: Matinya Pemasaran (Jakarta: Gramedia Pustaka Utama. 